\title{
Strategies for establishing sustainable safety inspection systems for existing multiple-unit dwellings in Korea
}

\author{
Park, Sang - Hoon $^{1} \quad$ Baek, Cheong - Hoon $^{2 *}$ \\ Yonsei University, Seodaemun-Gu, Seoul, 120-7749, Korea ${ }^{1}$ \\ Korea Institute of Construction Technology, IIsanseo-Gu, Gyeonggi-Do, 411-712, Korea ${ }^{2}$
}

\begin{abstract}
This study compares and analyses the existing safety inspection systems in Korea and Japan to establish and propose future safety inspection systems for multiple-unit dwellings in Korea. The results of the study are summarized below. First, the state of Korea's current safety inspection systems and policies for multiple-unit dwellings are compared with the systems and policies in Japan. Second, the differences between the safety inspection systems of the two nations are presented, and the issues in Korea are addressed. Third, methods to establish future safety inspection systems for multiple-unit dwellings based on the systems in Japan are proposed for application in Korea.
\end{abstract}

Keywords : existing multiple dwellings, safety inspection, building history information

\section{Introduction}

\subsection{Background and research objectives}

Housing supply policies in Korea are government-initiated and have tended to focus on new construction, which has resulted in a large number of housing units being built within a fairly short period of time. In the 1970s, the Housing Construction Promotion Act was formulated for economic stimulus, under which housing units were constructed on a huge scale. A plan for the "construction of five million housing units" was established at the beginning of the 1980s, resulting in a vast supply of housing. Housing shortages, however, had become a serious problem by the middle of the 1980s and into the 1990s

\section{Received : February 6, 2013}

Revision received : April 15, 2013

Accepted : May 14, 2013

* Corresponding author : Baek, Cheong-Hoon [Tel: 82-31-995-0856, E-mail: archihoony@gmail.com]

(c)2013 The Korea Institute of Building Construction, All rights reserved. because of the economic boom and the increasing urban population. In this context, two million housing units were built in five areas of "new town" development, including Bundang and Ilsan (the first "new towns").

In the 2000s, the large amount of new construction, together with social changes such as a lower birth rate and improvements in quality of life, resulted in an oversupply of housing units. The housing supply rate has reached $110 \%$, and the number of unsold new apartments has become a social problem. As such, there has been a shift from policies focused on quantitative housing supply to policies focused on the rehabilitation of existing housing units and improvements in the quality of life. In addition, nearly $80 \%$ of existing multiple-unit dwellings are approximately 20 years old. As such, it is predicted that maintenance, rehabilitation and sustainable safety inspection systems will emerge as critical issues in new housing policies in Korea.

Developed nations around the world have 
implemented green policies for energy conservation, and have made efforts to upgrade housing amenities to improve the quality of life. Likewise, Korea realized a national vision, an initiative for "Low Carbon, Green Growth" in 2008, focusing on reconstruction, redevelopment and sustainable development.

Despite social demands for the rehabilitation of existing houses, improvements in the quality of life and energy conservation, current inspection systems for safety and maintenance of buildings in Korea tend to focus only on the structural integrity of buildings. In effect, national housing policies thus far have progressed in association with the number of institutions for quantitative housing supply, with little consideration of the rehabilitation of existing units and improvements in the quality of life.

Japan is internationally renowned for its housing safety inspection systems. Japan implemented the Basic Law for Housing Life in 2006, under which all national policies were switched to become market-oriented and more concerned with the existing stock of housing rather than focusing on unnecessary new construction. The nation responds actively to changes in the housing environment, and examples of such active responses include preemptive measures to accommodate the aging society, housing reformation, promotion of secondhand houses, establishment of relevant laws, and revision of national housing policies to emphasize the maintenance of existing houses rather than new construction.

Though ideally an owner should voluntarily maintain his or her own house, the nation has established minimum criteria and enforces housing maintenance in the event of a threat to life or the public. From that point of view, the national criteria for housing maintenance are critically important. Therefore, the purpose of this study was to analyze and compare the sustainable safety inspection systems for multiple-unit dwellings in Korea and Japan, and to propose ways to improve Korea' s safety inspection systems.

\subsection{Objects and methods of research}

The research focus of this study was safety inspection stipulations in the relevant laws of Korea and Japan, including Korea' s Housing Act and Special Law for Safety of Facilities, and Japan' s Building Standard Act. In other words, 5-story or higher apartment buildings described as

'Apartment' in Korea and high-rise apartment houses (16-story or higher) stipulated in the Special Act on Facility Safety Management in Korea are targeted.

A review of the related literature identified the pertinent organizations, and on-site surveys and interviews with the people involved were carried out to examine the current circumstances and difficulties associated with safety inspection. The interviewees included professionals at institutions such as the Korea Infrastructure Safety \& Technology Corporation, Korea Land \& Housing Corporation, and Korea Institute of Construction Technology. In addition, the Tokyo Metropolitan Government, the Japan Building Disaster Prevention Association, Building and Equipment Life Cycle Association (BELCA), and the Machizukuri Center for Tokyo Metropolis Disaster Prevention were visited in order to obtain practical materials on safety inspection procedures in Japan.

The results of the interviews have been mostly reflected in the proposal of a direction for safety check on domestic apartment buildings. In addition, the current status of safety inspections on apartment buildings in Korea and Japan, which were investigated through a literature review, has been reconfirmed through the interviews.

These efforts were undertaken to analyze and 
compare safety inspection activities in Korea and Japan, and to present methods to improve the circumstances of Korea, which requires institutional changes.

\section{Policies for multiple-unit dwellings in Korea and Japan}

\subsection{Korea}

The Korean War severely damaged key industries and houses in Korea, after which most housing policies were associated with state-sponsored programs to supply houses and eliminate housing shortages for the displaced population. In the 1970s, the Housing Construction Promotion Act was formulated as the starting point for a large-scale national housing plan. A plan for the "construction of five million housing units" was established at the beginning of the 1980s and resulted in a vast supply of housing. The housing shortage, however, became a serious problem with the confluence of the economic boom and an increasing urban population between the mid-1980s and the beginning of the 1990s. In that context, two million housing units were built in five areas of "new town" development, including Bundang and Ilsan (the first "new towns"). A large population concentrated in a relatively small area was the main cause of the large--scale construction of apartment houses.

The construction industry occupied a large share of the economy from the 1990s to the 2000s. However, during the worldwide economic crisis, the construction industry suffered from serious financial problems. Under such conditions of financial hardship, the Korean government utilized housing policies as part of its plan for economic revitalization. The government at that time (the Roh Moo-hyun government), based on its commitment to welfare and distribution, concentrated on housing stabilization for the disadvantaged.

The 1990s saw a series of disastrous accidents, including the collapse of the Changseon Large Bridge, the Seongsu Large Bridge, and Sampoong Department Store. After these disasters, the government made efforts to systemize safety inspections and the maintenance of structures. In 1995, the government formulated the Special Law for Safety Management of Facilities (hereafter referred to as SLSMF), which assigned the obligations and responsibilities for housing maintenance to building managers. Stronger standards to assess the structural safety of facilities were also imposed.

In the 2000s, the excessive supply of houses, together with social changes such as a lower birth rate and improvements in quality of life, resulted in a surplus of housing units, with the housing supply rate reaching $110 \%$. The Housing Construction Promotion Act, on which the housing supply policies had been based, was completely revised and renamed the Housing Act (2003). The new act set a concrete target to switch from a focus on construction and quantitative supply to a focus on welfare, management, the environment, and other socially important issues (in research[1,2]).

The government announced a national vision of "Low Carbon, Green Growth" in 2008 and made efforts to control housing reconstruction and redevelopment. It also began to show an interest in policies to rehabilitate existing houses. The government's efforts for safety and ongoing maintenance of existing houses, however, were relatively insignificant in monetary terms. In total, the investment in maintenance for existing housing units was $0.65 \%$ (about 280 billion won) of the total investment in new construction.

In sum, since the Korean War, Korea has 
implemented government-initiated housing supply policies that have enabled the construction of a large number of housing units in a fairly short period of time. This focus led to the current oversupply of houses. In addition, nearly $80 \%$ of the multiple-unit dwellings in Korea are approximately 20 years old. It is thus anticipated that ongoing maintenance and rehabilitation of existing housing will emerge as imperative issues in future national housing policies.

\subsection{Japan}

Following the Second World War, the main focus of Japan's housing policies was government -initiated housing supply for the displaced population. There were serious housing problems at that time in Japan' s history because one-fourth of the population (about twenty million people) had lost their homes in the war, and numerous families were living in poor and overcrowded conditions. Due to this severe housing shortage after the war, the government intervened by providing public funds through institutional components and worked to supply houses.

In 1950, the Government Housing Loan Corporation of Japan (GHLC) was founded under the Housing Loan Corporation Act. In 1951, the Public Housing Act established a legal basis for the government to initiate the large-scale supply of new houses. With the foundation of the Japan Housing Corporation in 1955, the government created housing policies for home ownership, resulting in a $61.2 \%$ rate of home ownership in 2003 (Yoon et al.[3]).

As the number of mansions increased (in Japan, a multiple-unit dwelling is called a mansion), matters such as usage and resident management began to demand attention. Accordingly, the Divided Ownership Act was established in 1983, which stipulated specific roles for a community association for the management and seamless operation of the residents' community in a multiple-unit dwelling by majority vote.

Over time, legislation for the maintenance of multiple-unit dwellings was strengthened. In 1985, building maintenance was assigned to fall under legal control, and the Building Standard Act was established to specify compulsory, governmentsupervised safety inspections of building structures and fire prevention measures.

The catastrophic Hanshin Earthquake in 1995 led to the establishment of a law that made it easier to rebuild structures with shared ownership. Under the law, owners of any mansions that failed to meet the new criteria for earthquake resistance were forced to perform mandated reinforcement work.

Mansion management became an important issue as the number of mansions increased. Accordingly, the Act for Promotion of Mansion Management Optimization became effective in 2001, and included provisions for the inspection systems and required the registration of mansion managers.

Because of the predicted increase in the number of old mansions, new safety measures were required, such as the enactment of a law on mansion reconstruction. Consequently, the Act for Promotion of Mansion Reconstruction, Etc. was formulated in 2002 .

Recent social changes, such as the change in the focus of housing policies from quantity to quality, low birth rates, an aging society, and a decreasing number of families needing housing, have transformed current housing policies in Japan. The Basic Law for Housing Life (2006) specified improvements in housing amenities, rehabilitation of the existing stock of houses, and mandates to decrease levels of carbon dioxide, among other measures to improve the quality of residential life (Hirayama[4]). 


\section{Conditions of multiple-unit dwellings and} safety inspection systems in Korea and Japan

\subsection{Conditions of multiple-unit dwellings}

\subsubsection{Housing supply and proportion of multiple- unit dwellings}

There has been a rapid increase in Korea' $\mathrm{s}$ housing stock over the last few decades. Specifically, Korea' s housing stock included about $16,000,000$ units in 2005, which is 1.7 times the stock in 1995 and 2.6 times the stock in 1985. Multiple-unit dwellings have long accounted for a significant share (52.4\%) of the housing stock. Meanwhile, the rate of vacancies continued to increase, from 2.8\% in 1995 to 4.6\% in 2005, and the number of unsold new units reached as high as 120,000 in 2009, up from 57,000 in 2005 and 112,000 in 2007.

The housing stock of Japan included about 46,000,000 units in 2003, which is nearly 3.4 times the level in Korea. As in Korea, multiple-unit dwellings in Japan occupied a large proportion (about 40\%) of the entire stock of housing. The rate of vacancies was as high as $12.2 \%$ due to the number of aged houses and an increasingly aging population, among other social reasons.

\subsubsection{Proportion of high-rise multiple-unit dwellings}

As of 2005 in Korea (Table 1), the rate of multiple-unit dwellings taller than five stories was $39.4 \%$, and the rate of dwellings taller than 15 stories was $26.3 \%$. These percentages clearly show that high-rise units make up a substantial proportion of existing multiple-unit dwellings.

In comparison, in 2003 the national rate of multiple-unit dwellings taller than five stories was $17.5 \%$ in Japan, while the rate for the city of Tokyo was $31.7 \%$.
Table 1. Rates of mid- and high-rise dwellings in large cities (Unit: Thousand Families, \%)

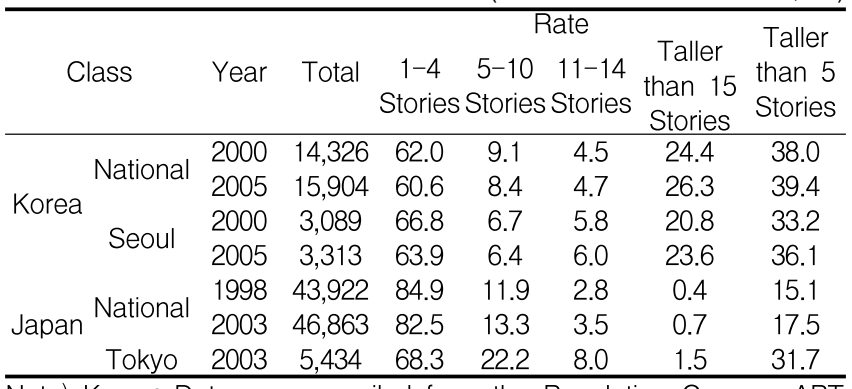

Note) Korea: Data was compiled from the Population Census, APT House Living Condition Statistics, and Yearbook of Housing \& Urban Statistics.

Japan: Data was compiled from the Housing and Land Statistics, The Ministry of Internal Affairs and Communications.

\subsubsection{Proportion of decrepit multiple dwellings}

With regard to the aggregate rates of housing units according to age (Table 2), the current percentage of houses up to 10 years old is $45.1 \%$ of total housing in Korea, while the percentage of houses up to 20 years old is $79.5 \%$, and the percentage of houses up to 30 years old is $94.3 \%$. That is, the majority of multiple-unit dwellings are 20 years old or more and will most likely require maintenance in the near future.

In Japan, houses that are as old as 13 years represent $34.8 \%$ of the total housing supply, while houses up to 20 years old represent $60.6 \%$, and houses up to 30 years old represent $82 \%$.

Table 2. Aggregate rates of houses according to age

\begin{tabular}{|c|c|c|c|c|c|c|c|c|}
\hline \multirow{2}{*}{$\begin{array}{c}\text { Class } \\
\text { (from } \\
\text { construction) }\end{array}$} & \multicolumn{4}{|c|}{ Korea } & \multicolumn{4}{|c|}{ Japan } \\
\hline & $\mathrm{N}$ & A.R. & Seoul & A.R. & $\mathrm{N}$ & A.R. & Tokyo & A.R. \\
\hline $\begin{array}{c}\text { over } 50 \\
\text { years }\end{array}$ & - & - & - & - & 44,665 & 100.0 & 4,816 & 100.0 \\
\hline $\begin{array}{l}\text { Up to } 50 \\
\text { years }\end{array}$ & 12,495 & 100.0 & 2,242 & 100.0 & 42,477 & 95.1 & 4,740 & 98.4 \\
\hline $\begin{array}{l}\text { Up to } 40 \\
\text { years }\end{array}$ & 12,084 & 96.7 & 2,224 & 99.2 & 41,090 & 92.0 & 4,601 & 95.5 \\
\hline $\begin{array}{l}\text { Up to } 30 \\
\text { years }\end{array}$ & 11,782 & 94.3 & 2,185 & 97.4 & 36,610 & 82.0 & 4,086 & 84.8 \\
\hline $\begin{array}{l}\text { Up to } 20 \\
\text { years }\end{array}$ & 9,928 & 79.5 & 1,817 & 81.1 & 27,069 & 60.6 & 3,135 & 65.1 \\
\hline $\begin{array}{l}\text { Up to } 10 \\
\text { years }\end{array}$ & 5,629 & 45.1 & 1,018 & 45.4 & 15,549 & 34.8 & 1,815 & 37.7 \\
\hline $\begin{array}{l}\text { Note) } \\
\mathrm{N}=\text { Nat } \\
\text { For Ja } \\
\text { repres } \\
\text { Korea } \\
\text { Japan } \\
\text { Affairs }\end{array}$ & $\begin{array}{l}\text { nal, A. } \\
\text { an, the } \\
\text { tt perc } \\
\text { Popula } \\
\text { Housin }\end{array}$ & $R .=A g$ & regate & Rate & $\begin{array}{l}\text { up to } \\
\text { tics Kor } \\
\text { he Mini }\end{array}$ & $a, 2$ & $\begin{array}{l}\text { s old } \\
\text { ars old. } \\
05 \\
\text { Interna }\end{array}$ & \\
\hline
\end{tabular}




\subsection{Conditions of safety inspections for multiple- unit dwellings in Korea and Japan}

\subsubsection{Japan}

Article 8 of the Building Standard Act stipulates that the site, structure and facilities of a building should be appropriately maintained for safety by the owner of the site. The owner of a special structure or a structure over a certain size must maintain the structure and report a maintenance plan according to the specifications designated by a relevant administrative agency. However, these provisions are obligations of effort on the part of building owners and as such are not associated with a penalty for neglect.

Article 12 of the Building Codes stipulates that building owners should request a qualified expert to inspect their buildings with regard to sites, structures, and building facilities (Table 3). Furthermore, owners should report the results of inspections to the corresponding administrative agencies.

Table 3. Type, size and inspection time of special structures

\begin{tabular}{|c|c|c|}
\hline Purpose & Size & Inspection Time \\
\hline (1) Buildings & & \\
\hline $\begin{array}{l}\text { Cinema, image } \\
\text { exhibition hall or } \\
\text { theater }\end{array}$ & $\begin{array}{l}F=3 \text { and } A=200 \mathrm{~m}^{2} \text { or } \\
\text { buildings with the main } \\
\text { stairway on floors other } \\
\text { than the 1stfloor }\end{array}$ & Every 1 year \\
\hline $\begin{array}{l}\text { Show room, public } \\
\text { hall or meeting hall } \\
\text { Hospital, clinic, }\end{array}$ & $F=3$ or $A=200 \mathrm{~m}^{2}$ & Every 1 year \\
\hline $\begin{array}{l}\text { nursing home, child } \\
\text { welfare institution, } \\
\text { etc. }\end{array}$ & $F=3$ or $A=300 \mathrm{~m}^{2}$ & Every 3 years \\
\hline $\begin{array}{l}\text { Motel or hotel } \\
\text { Boarding house, }\end{array}$ & $F=3$ or $A=300 \mathrm{~m}^{2}$ & Every 3 years \\
\hline $\begin{array}{l}\text { multipledwelling or } \\
\text { dormitory }\end{array}$ & $F=5$ or $A=1000 \mathrm{~m}^{2}$ & Every 3 years \\
\hline School or gymnasium & $F=3$ or $A=2,000 \mathrm{~m}^{2}$ & Every 3 years \\
\hline $\begin{array}{l}\text { Museum, art gallery, } \\
\text { library, etc. } \\
\text { Department store, }\end{array}$ & $F=3$ or $A=2,000 \mathrm{~m}^{2}$ & Every 3 years \\
\hline $\begin{array}{l}\text { supermarket, } \\
\text { exhibition center, } \\
\text { restaurant, or shop }\end{array}$ & $F=3$ or $A=500 \mathrm{~m}^{2}$ & Every 3 years \\
\hline $\begin{array}{l}\text { Business, etc. } \\
\text { (2) Elevators } \\
\text { (3) Building Facilities }\end{array}$ & $\begin{aligned} & F=5, A=1,000 \mathrm{~m}^{2} \\
&- \\
&-\end{aligned}$ & $\begin{array}{l}\text { Every } 3 \text { years } \\
\text { Every } 6 \text { months } \\
\text { Every } 6 \text { months }\end{array}$ \\
\hline Note) Standards for & ular Inspection of S & Structures, etc., \\
\hline
\end{tabular}

Quasi-public buildings, as well as buildings used by many and unspecified persons, are primary targets for safety inspections. Accordingly, the sites, structures, and facilities of buildings designated as such by corresponding administrative agencies are inspected.

The Housing Administration of the Ministry of Construction (1985) enforces regular inspection reports (according to Article 12 of the Building Standard Act for the determination of items for regular inspection) at designated times, which vary according to building purposes (ranging from every six months to every three years).

Multiple-unit dwellings that contain more than five floors and which are larger than 1,000 square meters in area are inspected every three years. For escalators and other building facilities, relevant laws (the Fire Services Act and the Waterworks Law, among others) mandate regular inspection every six months (according to BELCA[5]).

First-class or second-class certified architects or those who meet the requirements of the Ministry of Land, Infrastructure, Transport and Tourism are qualified to conduct regular inspections for special structures. The procedure for regular inspections is as follows. To conduct a proper inspection, the inspector first interviews the people associated with the structure, such as building managers, regarding the conditions, the management system and the history of the building in question. If need be, the inspector consults a fire prevention manager. After checking historical documentation, the inspector prepares an inspection plan and carries out the inspection, drawing up a list of inspection results. Finally the inspector reports the results and counsels the people or organization that originally requested the inspection[19]. The owner or manager of the special structure reports the results of the inspection to the appropriate administrative agencies. By law, the person who 
actually conducted the inspection can be asked for a more detailed report in cases where abnormalities are found by agency review.

The inspection rate is $88.6 \%$ in Tottori Prefecture, 65.1\% in Tokyo Prefecture, and 12.6\% in Okinawa Prefecture. The average national rate of reporting is $60.2 \%$ (AIJ[6]).

In addition, Japan has a system for tracking building information history, called Mansion Mirai Net, which covers all recorded information about existing buildings, including regular inspection data. The purpose of the system is to promote the proper maintenance of mansions and the ownership of secondhand mansions. The Mansion Management Center designed the system in 2006 under the sponsorship of the Ministry of Land, Infrastructure, Transport and Tourism. The system targets common housing units, regardless of the number of floors or spatial area, and includes brief descriptions of buildings, rules of management, commissioned management and operation of community associations, accounting practices, repair plans and history, and so on. In sum, the system is organized to inform users not only of the history of regular inspections, but also of the overall history of the building.

\subsubsection{Korea}

Legislation on the regular inspection of multiple-unit dwellings in Korea includes provisions in the Housing Act and the SLSMF.

The Housing Act stipulates that a multiple-unit dwelling having more than 300 families or a multiple-unit dwelling having more than 150 families and equipped with elevators or a central heating system should receive regular safety inspection and maintenance. According to the Housing Act, such dwelling units should have housing managers who deal with both engineering and management works, including the resolution of conflicts between residents, personnel management and accounting.

A designated employee from an apartment complex's managing staff conducts safety inspections twice a year. A housing manager or a safety inspection company checks the structures and facilities. The results of inspections are reported to corresponding administrative agencies only in cases where there is a noticeable threat to the safety of the building structure or facilities.

Thorough evaluation of facilities such as electric installations, gas facilities, and fire-fighting equipment are included in regular safety inspections, and inspection results are reported in accordance with the relevant laws.

Another pertinent law for housing maintenance, the SLSMF, requires that buildings over a certain size undergo safety inspection and precise safety diagnosis.

A series of fatal collapses of public structures in the 1990s necessitated improvements in building safety, efficiency and performance for the sake of public safety. The SLSMF was established in 1995 as an important part of such efforts to protect the public. The SLSMF systemizes safety inspections and maintenance for structures, and assigns to building managers the obligations and responsibilities of housing maintenance.

The structures looked after by the SLSMF are divided according to size into first-class and second-class facilities. First-class facilities include buildings that contain 21 stories or more or that are larger than 50,000 square meters in area. Second-class facilities include buildings that have 16-20 stories and those that are larger than 30,000 square meters in area.

Under the SLSMF, 54,940 facilities are protected (Table 4), including 6,831 first-class facilities and 48,109 second-class facilities. Of the total facilities, buildings represent the largest share at 
40,083, $73 \%$ of all facilities under the SLSMF. Most of the facilities (24,808 facilities, comprising $51.3 \%$ of the total) are in metropolitan areas, including Seoul.

The SLSMF requires that data about the facilities controlled therein be contained in the Facility Management System. System data includes a brief description of a facility, designs and specifications, related companies, and technical data and statistics, among other types of information (Gwon[7]). The system is limited to buildings with 16 stories or more. Furthermore, data supplied by the system has often been considered unreliable because inaccurate building data is often entered into the system in order to pass inspections and to prevent decreases in housing prices. Since data about the history of buildings is unavailable to the general public, the system has been criticized for not being transparent (various research results $[8,9,10])$.

Table 4. Conditions of facilities controlled under the SLSMF

\begin{tabular}{|c|c|c|c|c|c|c|c|c|c|}
\hline Type & 2002 & 2003 & 2004 & 2005 & 2006 & 2007 & 2008 & 2009 & 2010 \\
\hline Total & 30,668 & 33,295 & 36,507 & 38,929 & 42,157 & 45,745 & 48,2985 & 51,645 & 54,940 \\
\hline Road & 4,986 & 5,255 & 5,906 & 6,291 & 6,867 & 7,566 & 7,778 & 8,409 & 8,177 \\
\hline Railroad & 1,393 & 1,445 & 1,525 & 1,567 & 1,611 & 1,794 & 1,835 & 1,915 & $2,11 \mathrm{c}$ \\
\hline Port & 226 & 229 & 238 & 244 & 253 & 258 & 262 & 288 & 297 \\
\hline Dam & 60 & 60 & 60 & 61 & 98 & 105 & 384 & 521 & 52 \\
\hline Building & 21,921 & 24,139 & 26,478 & 28,379 & 30,754 & 33,156 & 35,0103 & 37,172 & 40,083 \\
\hline River & 552 & 554 & 566 & 577 & 597 & 719 & 753 & 952 & 1,16 \\
\hline $\begin{array}{l}\text { Water \& } \\
\text { Sewage, } \\
\text { Landfill }\end{array}$ & 1,048 & 1,111 & 1,175 & 1,216 & 1,265 & 5 1,309 & $\begin{array}{ll}9 & 1,362\end{array}$ & 1,386 & 1,411 \\
\hline $\begin{array}{c}\text { Retaining } \\
\text { Wall }\end{array}$ & 348 & 361 & 395 & 423 & 512 & 612 & 675 & 753 & 856 \\
\hline $\begin{array}{c}\text { Cut } \\
\text { Slope } \\
\end{array}$ & 134 & 141 & 164 & 171 & 200 & 226 & 239 & 249 & 314 \\
\hline
\end{tabular}

\subsection{General opinions}

Korea' s housing stock consists of 16,000,000 units (2005). Even though this number is smaller than that of Japan $(46,000,000$ units in 2005), it is an enormous stock considering that the Korean population is one-third the Japanese population. The surplus supply of housing in Korea has led to the present supply rate of $110 \%$ and to the large number of unsold new dwellings. Now is the right time for a shift in housing policies, from a focus on new construction to a focus on the rehabilitation of existing dwellings.

In Korea, multiple-unit dwellings with more than five floors account for $39.4 \%$ of all multiple-unit dwellings, which is much higher than the rate in Japan (17.5\%). The relatively high proportion of multiple-unit dwellings means that the need for safety inspections for mid- and high-rise buildings in Korea should be highlighted.

It has been about 20 years since the large-scale construction of apartment houses in the first "new towns," including Bundang and Ilsan, as well as in Seoul. Before long, these original apartment houses will be in urgent need of maintenance. The rest of this paper discusses the preparation of sustainable safety inspection systems for multiple-unit dwellings in Korea. By introducing the conditions for safety inspections in Korea and Japan, we present ways to establish effective safety inspection systems for multiple-unit dwellings in Korea.

\section{Analysis and comparison of safety inspection systems in Japan and Korea}

\subsection{Applicable laws}

In Japan, safety inspections of dwellings are regulated by the Building Standard Act. Regular inspection of elevators and buildings is governed by Article 12 of the Building Codes, but other facilities are controlled by more specialized laws such as the Fire Services Act, Waterworks Law, Electricity Enterprises Act, and the Septic Tank 
Law (conventional study[5]).

In Korea, the safety inspection of housing is governed by the Housing Act and the SLSMF. The Housing Act is applicable to multiple-unit dwellings with a certain number of units (150 to 300), and the SLSMF covers multiple-unit dwellings that are 16 stories or higher and those that are larger than a certain area. The SLSMF regulates the safety inspection not only of buildings, but also of other large facilities.

The safety inspection of elevators is governed by the Elevator Manufacture and Management Act. Other facilities are governed by facility-specific laws, such as the Fire Services Act, Electricity Enterprises Act, Law for Safety Management of High Pressure Gas, and Regulations on Cleaning and Maintenance of Water Supply Systems (Ha and Park[11]).

\subsection{Buildings requiring a safety inspection}

In Japan, multiple-unit dwellings with five stories or more and those larger than 1,000 square meters in area are inspected. The site, structure and facilities of such dwellings are the objects of regular inspections. The facilities inspected include elevators, firefighting equipment, water supply systems (water quality), private electric installations, and septic tanks, among others.

In Korea, multiple-unit dwellings with more than 300 units or with more than 150 units and equipped with elevators or a central heating system must undergo regular safety inspection in accordance with the Housing Act. It is prescribed in the SLSMF that safety inspections must be conducted for buildings with 16-20 stories and buildings larger than 30,000 square meters in area. There is a further requirement for a precise safety diagnosis for buildings with 21 stories or more and buildings larger than 50,000 square meters in area. Multiple-unit dwellings having no obvious danger, however, are exempt from the safety inspection.

\subsection{Inspection time and frequency}

In Japan, buildings are inspected on a regular basis every three years. In terms of facilities, elevators and fire systems are checked every six months. A complete inspection of facilities is conducted at least once a year, including the safety inspection of facilities such as water supply and electric systems, and these are carried out according to facility-specific laws.

In Korea, safety inspection under the Housing Act is carried out at least two times every year. According to the SLSMF, regular safety inspections are performed at least twice every year, and a precise diagnosis is conducted every three years. As for facilities, regular inspections of elevators are conducted at least once every year, inspection of the operation and performance of fire-fighting equipment is carried out at least twice a year, and a complete and precise check of equipment is conducted once or more every year. Other facilities, including electric and sanitation systems, are inspected in accordance with relevant laws.

\subsection{Items of inspection}

Japanese law regulates safety inspection of the site and grounds, the exterior, the roof and rooftop, the interior, and the escape facilities of buildings, among a long list of items for safety inspection in buildings. The inspection of the site and grounds involves the inspection of passages on the grounds, the main gates and passages of a multiple-unit dwelling, windows, vacant lots, outdoor passages, walls, retaining walls, cliffs, and any advertising towers or billboards installed on the site. Inspection of the exterior of a building is conducted to evaluate foundations and outer walls for safety. Inspection of the roof and rooftop includes checking the rooftop' s surroundings, the 
integrity of the roof itself, rooftop facilities and installations. Inspection of the interior of a building includes fire prevention sections, inner walls, floors, ceilings, firefighting equipment, lighting fixtures, banners, lighting and ventilation in living rooms, and evaluation of any building materials containing asbestos.

As for escape facilities, inspection is carried out for passages, hallways, exits, rooftop decks, balconies and stairs for escape, and smoke exhaust equipment, among others. Underground shopping areas, special structures, lightning protection systems, chimneys, and revolving doors are also checked during standard safety inspections.

Pertinent inspection laws stipulate the inspection of items for facilities such as elevators, firefighting equipment, water supply systems (water quality), private electric installations, and septic tanks.

In Korea, the laws concerned with safety inspections have specific provisions for regular, precise, and emergency inspections. Precise inspections are comprised of the same items for inspection as are included in emergency inspections. Items for regular inspection include any changes to the building, changes in structural members, changes in loading conditions and foundations, condition of cracks, overall condition of structures or structural members, and the state and documentation of repairs or works of reinforcement. A precise inspection covers the specifications of main structural members, the strength of concrete through non-destructive examination, the condition of reinforcement in ferroconcrete, and the carbonation of concrete, as well as designs for earthquake resistance and wind resistance. Inspection of facilities applies to elevators, electric installations, fire-fighting equipment, gas facilities, and sanitation systems.

\subsection{Qualifications for inspection}

Regular inspections for multiple-unit dwellings in Japan are carried out by first-class or second-class architects or by qualified inspectors of special structures. Elevators are inspected by those qualified for elevator inspection or by first-class or second-class architects. Firefighting equipment is inspected by firefighting engineers (Class A and Class B) or by those qualified for firefighting inspection (first-class and second-class).

Companies registered with the Ministry of Health, Labor and Welfare for water quality inspection are qualified to inspect the quality of water flowing through water supply systems. Chief electrical engineers (first- to third-class) are qualified to inspect private electric installations. Technology managers for septic tanks (i.e., specialized managers for septic tanks) are qualified to clean, inspect, and maintain the tanks.

Housing managers or deputy housing managers are qualified to conduct safety inspections of multiple-unit dwellings in Korea. As for building facilities, elevators can be inspected by engineers, industrial engineers, or specialized craftsmen for elevators, as well as those with certain academic or career backgrounds. Electric engineers are qualified to inspect electric equipment. Fire-fighting equipment managers, fire-fighting equipment engineers, industrial safety engineers, or registered architects are qualified for inspection of fire-fighting equipment. Gas engineers inspect gas facilities. Craftsmen or chemical craftsmen are qualified to inspect high-pressure gas, as well as high-pressure gas machinery. Environmental engineers inspect sanitation systems.

\subsection{General analysis}

In Japan, buildings with five or more floors are subject to safety inspection. Safety inspections are 
meant to evaluate not only the structural performance of buildings, but also the site, grounds, exterior, roof and rooftop, interior, and escape facilities. That is, the whole of a building is comprehensively checked. As emphasized, items that have a meaningful impact on the quality of life for residents, such as the grounds around a building, lighting, ventilation, and the presence of asbestos, are checked as a part of standard safety inspections. Architects or other professionals qualified for safety inspection (inspectors qualified for special structures) carry out all inspections in Japan.

Safety inspections for buildings in Korea are limited to multiple-unit dwellings with 16 or more floors. Compared to Japan, the range of the targets of inspection is much narrower (Shin[12]).

It is necessary to expand the scope of inspection in Korea, because buildings with 16 floors or less represent a substantial proportion of all buildings (approximately 74\%). Furthermore, small buildings often have poor safety management.

Above all, it is imperative to develop qualifying skills to conduct safety inspections. Housing managers are required to conduct safety inspections in Korea, and are responsible for engineering (safety inspections) and administrative works for multiple-unit dwellings (KHMA[13]). However, housing managers are rarely provided with appropriate education about architecture or construction. It is urgently necessary to enhance the professional skills of housing managers (Lee[14]). The few human resources that currently have experience and knowledge of specialized areas of safety inspection will not be able to actively respond to the increasing demand for safety inspections.

Safety inspections in Korea mainly cover the conditions and any changes in structures, such as changes in buildings, changes in structural members, changes in loading conditions and foundations, the condition of cracks, and the overall condition of structures and their components (Park[15]). On the other hand, safety inspections in Japan take into account conditions of the housing such as the grounds, lighting, ventilation, presence of asbestos, and escape facilities (including passages, hallways, and exits). Standard safety inspections of dwellings in Korea need to include the inspection of such items that have meaningful impacts on the quality of residential life.

\section{Proposal of directions for safety inspections}

\subsection{Changes in items for safety inspection in consideration of quality of life}

Items requiring safety inspection in Korea are mainly related to structural matters of buildings (Jeon[16]). A series of structure collapses in the 1990s contributed to the current primary focus on structural items for safety inspection. Issues such as housing environment, quality of housing, and energy conservation have been receiving an increasing amount of attention recently. Safety inspections need to include requisites for lighting, ventilation, presence of asbestos, fire-fighting, escape facilities, energy conservation, and so on in order to address current issues such as the need to improve the quality of life for residents and to develop eco-friendly buildings for environmental protection.

\subsection{Increasing the number of buildings requiring safety inspection and establishing a system of building history}

Seoul enforces safety inspection for buildings with more than 150 units or with more than 16 floors, while buildings with 16 or fewer stories are not required to undergo a safety inspection. Safety inspection laws were enacted in 1995 after a series 
of disastrous accidental collapses of public structures, and deal mainly with large facilities. As such, mid-rise multiple-unit dwellings (with fewer than 16 floors) have no legal safeguards. For this reason, it is necessary to impose safety inspections for multiple-unit dwellings with 16 or fewer stories (Kim and An[17]). For the sake of comparison, Japan enforces safety inspections on any buildings with more than five floors, and the city of New York in the United States regulates safety inspections for buildings taller than six floors (Hong[18]).

In Korea, only buildings that have 16 or more stories are compelled to submit data to the Facility Management System (FMS), which is the national system for tracking building history. Thus, few buildings with fewer than 16 floors have undergone safety checks and have no system of recorded history.

Considering the weight currently given to environmentally friendly buildings, the management bodies of buildings need to input data in the proposed building history system with a focus on current government policies. For instance, an optimal system would keep track of data relating to energy conservation policies (e.g., operation-related conservation systems for existing buildings, conservation systems for equipment and materials using energy, etc.), and eco-friendly certifications (e.g., energy efficiency rating systems, eco-friendly certification systems, housing performance indication systems, etc.). With a system to record building history, information about energy loads and conservation can be preserved (John et al.[19]).

Reliability is the most critical quality of such a building history system. Institutional devices are needed in order to make the information contained within the building history system available to the public (however; depending on the type of information, some data may remain unavailable to the public) and to prevent the propagation of inaccurate data.

In addition, data about disaster prevention, as well as eco-friendly information, needs to be added to the list of items for safety inspection. Japanese law stipulates inspections for emergency escape facilities. Since multiple-unit dwellings with five or more stories account for a substantial proportion of all buildings in Korea, the organization of building history and systems for regular safety inspection is required for optimal building management and maintenance (Lo[20]). Such efforts will lay the foundation for sound structures and sustainable circulation of second-hand dwellings over the longer term.

\subsection{Development of professional manpower and qualifications for safety inspection}

According to Japanese law, only skilled professionals, such as architects and inspectors qualified for the inspection of special structures and registered with the Japan Building Disaster Prevention Association, are allowed to conduct safety inspections for buildings.

In accordance with the Housing Act in Korea, housing managers can independently perform safety inspections on multiple-unit dwellings. Housing managers, despite being required to attend legal education courses, have few opportunities to learn the intricacies of architecture and construction. The safety inspection of buildings is so closely connected with public safety that only professionals should be allowed to conduct such inspections. Ideally, qualified architects, engineers, or pertinent organizations should be responsible for all aspects of regular safety inspection that demand specialized skills.

Furthermore, qualifications for inspections should vary according to conditions, such as when there 
is a large number of families residing in a multiple-unit dwelling, for example, and should take into account the diversity of life styles.

Japan requires various qualifications, not only for qualified architects and inspectors regarding special structures, but also for mansion executive managers, mansion maintenance engineers, and construction equipment engineers, among others. These experts perform various duties, including providing advice and counseling for community associations, community association management, building diagnosis, deterioration checks for construction finishing materials, and repair and deterioration checks for facilities (Park[21]).

Thus, Korea needs to develop specialized qualifications for safety inspections and maintenance works. Some examples are certification for community association management (to provide support for optimal operation of community associations, advice and counseling, association control, etc.), certification of property management (e.g., property management, financial management, and building management), and certification for building diagnosis and inspection of finished materials and facilities. Since there are a large number of high-rise residential buildings accommodating many families in Korea, certifications on safety inspections for buildings and facilities, optimal operation of community associations, and counseling should be prioritized.

In Korea, approximately $80 \%$ of all housing units are about 20 years old. For this reason, it is necessary to develop means of certification for the inspection of facilities, pipelines, and finishing materials (e.g., outer walls and tiles) in addition to main structural parts. It is critical to establish qualification criteria for experts to provide advice and counseling about repairs and reconstruction. Effective continuing education is also required for professionals. To date, housing managers have been provided with one-time statutory education. They should be required to attain certain credits through continuing education, even after being designated as managers, in order to continue to develop their skills in required fields. Therefore, it is important to formulate a system of continuing education by which certified engineers can be re-designated by attaining specific credits through attending courses, workshops, conferences, and seminars at specialized institutes.

\section{Conclusions and future research}

Since the Korean War, the focus of housing policies in Korea has been the quantitative supply of new construction. In the 2000s, the excessive construction of houses, together with social changes such as low birth rates and improved quality of life, resulted in an oversupply of housing units. The housing supply rate reached $110 \%$, to the extent that unsold new apartments could be described as a social problem. It is therefore necessary to shift the focus of housing policy from one of quantitative housing supply to the rehabilitation of existing units and improvements in quality of life for residents (Park and $\mathrm{Oh}[22])$.

In addition, nearly $80 \%$ of multiple-unit dwellings are about 20 years old. As such, maintenance, rehabilitation, and safety inspection will emerge as critical matters in effective housing policies of the future. Accordingly, the safety inspection systems of Korea and Japan were compared and analyzed in order to establish best practices for future safety inspection systems for multiple-unit dwellings in Korea.

This study analyzed the safety inspection systems of Japan and, by comparison, presents the best methods to institute sustainable safety 
inspection systems for existing multiple-unit dwellings in Korea. The results of the study are summarized below.

First, by studying safety inspection systems for multiple-unit dwellings as they are conducted in Japan, the conditions of safety inspection systems and the policies for multiple-unit dwellings in Korea were examined. Through this comparison, the weaknesses in Korean safety inspection systems were revealed, along with necessary means to improve them.

Second, housing circumstances in Korea and Japan were analyzed and compared, including the laws on safety inspection for multiple-unit dwellings, the objects and items of inspection, qualifications for inspection, building history systems, and qualified professionals that are able to conduct safety inspections. Through analysis and comparison, the differences between the systems of the two nations and the issues that need to be addressed in Korea were presented.

Third, ways to establish future safety inspections for multiple-unit dwellings and ways to enhance the current systems were proposed based on the safety inspection systems of Japan. Since standard safety inspections in Korea concentrate only on structural aspects of buildings, Japan's more comprehensive safety inspection systems are a model on which this study proposes better practices for the safety inspection of multiple-unit dwellings in Korea. In future research, the safety inspection systems of Europe and the United States should be studied.

\section{Acknowledgement}

This research was supported by a grant(No 2012R1A1A2042535, No. 2012R1A1A2044577) from National Research Foundation of Korea(NRF) funded by the Korea government(MEST).

\section{References}

1. Park TG. A Study on Methodology for Optimal Designing of Apartment Houses through Life Cycle Cost Analysis [Dissertation]. [Seoul (Korea)]: Seoul National University; 2002. p. $182-5$.

2. Kim JR. Jae HS. A Study on State of Repair \& Replacement Cycle Calculation for Structures, and Improvement. Journal of the Korea Institute of Building Construction. 2010 Jan;16(1):4-6.

3. Yoon JH. Gang MN. Park CG. Changes in Japanese Housing Policies, and Establishment and Implications of Housing Life Master Plan. 1st ed. Seoul: Policies on National Land of Korea Research Institute for Human Settlements; 2006. p. $2-24$.

4. Hirayama Y, Ronald R. Housing and Social Transition in Japan. 1st ed. Tokyo (Japan): Routledge; 2007. p. 73-93.

5. Building and Equipment Life Cycle Association(BELCA). Standards for Regular Inspection Works for Special Structures, Etc. 1st ed. Tokyo (Korea): BELCA; 2005. p. 209-22.

6. Architectural Institute of Japan(AIJ). The Legal System in the Era of Housing Stock. 1st ed. Tokyo (Japan): AIJ; 2008. p. $2-7$.

7. Gwon CH. Examples of Successful Establishment of Preventive Maintenance Information Systems. 1st ed. Seoul (Korea): Korea Infrastructure Safety \& Technology Corporation; 2007.

p. $1-5$.

8. Jin GH. Choi MJ. Lee GS. Strategies to Introduce an Asset Management System for Maintenance of Infrastructure. Korean Journal of Construction Engineering and Management. 2009 Jun;10(6):67-9.

9. Jin SY. Kim HN. Development of the Model and System for Exterior Inspection and History Management in Safety Diagnosis for Buildings. Journal of the Architectural Institute of Korea. 2002 Apr;18(4):139-41.

10. Kang MS. Lee JW. A Basic Study on Web-Based Systems for Multiple Dwelling Maintenance. Journal of the Architectural Institute of Korea. 2002 Dec;16(12):109-1.

11. Ha MH. Park JS. Estimation of National Damage by Poor Precise Inspection and Safety Diagnosis. Structure Diagnosis Society. 2010 Jun;14(6):246-52.

12. Sin EY. Methods to Change Facilities under Special Law for 
Safety Management of Facilities. 1st ed. Seoul (Korea): Korea Institute of Construction Engineering and Management; 2009. p. 28-30.

13. Korea Housing Managers' Association(KHMA), Korea Housing Managers' Association Handbook. 1st ed. Seoul: Korea Housing Managers' Association; 2008.

14. Lee JB. Measures for Efficiency of Maintenance of Multiple Dwellings, with AHP Technique. 1st ed. Seoul (Korea): Korea Institute of Construction Engineering and Management; 2008. p. 70-8.

15. Park SH. A Study on Systems of Korea, Japan and the U.S. for Supporting Maintenance of Multiple Dwellings [Dissertation]. [Tokyo (Japan)]: The University of Tokyo; 2009. p. $47-142$.

16. Jeon JY. Directions of Systemization and Development for Building Maintenance Field of Korea. 1st ed. Seoul (Korea): Korea Institute of Construction Engineering and Management; 2007. p. 19-21.

17. Kim SW. An GH. A Study on the Problem and Improvement of Safety and Maintenance Management. Structure Diagnosis Society. 2009 Apr;13(4):101-6.

18. Hong JC. The Current Status of Structural Maintenance Inspection and its Improvement [Master's Thesis]. [Seoul (Korea)]: Hanyang University; 2001. p. 15-25.

19. John HL, Genevieve K, Kenneth WT. Environmental site assessments and audits: Building inspection requirements Environmental Management. 1994 Jan;18(1):151-60.

20. Lo SM. A Fire Safety Assessment System for Existing Buildings. Fire Technology. 1999 Feb;35(2): 131-52.

21. Park SH. A Study on Development of Maintenance Engineers for Multiple Dwellings. Korea Institute of Ecological Architecture and Environment. 2010 Apr;10(4):29-37.

22. Park SH. and Oh EH. Proposal of directions for the establishment of loan programs for the promotion of apartment houses maintenance in Korea. Renewable and Sustainable Energy Reviews. 2011 Jun;15(6):2643-54. 